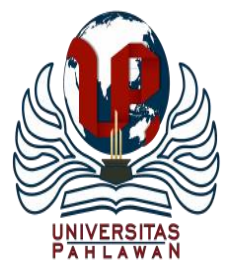

Edukatif : Jurnal Ilmu Pendidikan Volume 3 Nomor 4 Tahun 2021 Halm 1890 - 1900

EDUKATIF: JURNAL ILMU PENDIDIKAN

Research \& Learning in Education

https://edukatif.org/index.php/edukatif/index

\title{
Analisis Kebutuhan Pengembangan E-Modul Materi Bilangan Pecahan di Sekolah Dasar
}

\author{
Elsa Nur Qomalasari ${ }^{1 凶}$, Karlimah $^{2}$, Resa Respati ${ }^{3}$ \\ Universitas Pendidikan Indonesia, Indonesia ${ }^{1,2,3}$ \\ E-mail : elsanurq@ upi.edu ${ }^{1},{\underline{\text { karlimah@ } \text { upi.edu}^{2}}} \underline{\text { respati@upi.edu }}^{3}$
}

\begin{abstract}
Abstrak
Penelitian ini bertujuan untuk menganalisis kebutuhan pengembangan e-modul pada materi bilangan pecahan di Sekolah Dasar. Salah satu landasan dilakukannya penelitian ini adalah data rendahnya kemampuan matematika peserta didik yang dibuktikan oleh PISA. Hal ini memproyeksikan untuk menganalisis kualitas pembelajaran dengan fokus terhadap bahan ajar e-modul yang ditunjang dengan pemanfaatan teknologi. Metode yang digunakan adalah metode penelitian deskriptif kualitatif dengan teknik pengumpulan data dari wawancara, observasi dan studi dokumentasi. Lokasi penelitian ditentukan berdasarkan akreditasi dan prestasi sekolah di Kecamatan Luragung, Kuningan. Waktu penelitian dilakukan selama tiga bulan pada bulan MaretMei 2021. Penelitian ini memperoleh hasil bahwa terdapat keterbatasan akan penggunaan bahan ajar non-cetak, materi bilangan pecahan merupakan materi yang paling sulit untuk dikuasai, rendahnya kreativitas pendidik dala pembelajaran, dan rendahnya pembiasaan kemampuan pemecahan masalah serta kemampuan berpikir tingkat tinggi peserta didik. Dengan demikian, pengembangan e-modul ini menjadi kebutuhan untuk menyediakan bahan ajar yang sesuai dengan kebutuhan akan tuntutan kemampuan yang perlu dimiliki peserta didik.
\end{abstract}

Kata Kunci: analisis kebutuhan, e-modul, matematika, bilangan pecahan.

\begin{abstract}
This study aimed to analyze the need for developing e-modules in fractional numbers at elementary schools. One of the reason did the research is caused of the low mathematical ability of student by PISA. It is projected to analyze the quality of learning focused on teaching materials used as e-module which is supported the use of technology. The method used was a qualitative descriptive method using data collection techniques from interviews, observations, and documentation studies. The research location determined based on accreditation and school achievement in Luragung District, Kuningan Regency. The time of the research carried out for three months in March-May 2021. This study obtained the results that there were limitation to use non-printed teaching materials, fractional number material was the most difficult material to master, low creativity of educators in learning, and low habituation of problem solving and higher order thinking skills from students. Thus, the development of this e-module becomes a necessity to provide teaching materials according to the need of students as a demand of output learning.
\end{abstract}

Keywords: need analysis, e-module, mathematics, fractional number.

Copyright (c) 2021 Elsa Nur Qomalasari, Karlimah, Resa Respati

$\triangle$ Corresponding author

Email : elsanurq@upi.edu

DOI : https://doi.org/10.31004/edukatif.v3i4.1027 ISSN 2656-8071 (Media Online) 
1891 Analisis Kebutuhan Pengembangan E-Modul Materi Bilangan Pecahan di Sekolah Dasar - Elsa Nur

Qomalasari, Karlimah, Resa Respati

DOI: https://doi.org/10.31004/edukatif.v3i4.1027

\section{PENDAHULUAN}

Matematika adalah salah satu muatan mata pelajaran yang ada pada kurikulum 2013 yang bertujuan untuk dapat membekali peserta didik agar memiliki kemampuan berpikir logis, kritis, sistematis dan dapat meningkatkan kemampuan peserta didik dalam menyelesaikan masalah dalam kehidupan sehari-hari. Pencapaian pembelajaran matematika dilihat dari keberhasilan siswa dalam memanfaatkan matematika untuk memecahkan masalah yang berkaitan dengan matematika (Badaruddin et al., 2016, hlm. 44). Oleh karena itu, kemampuan tertinggi dalam matematika adalah pemecahan masalah. Akan tetapi, pelaksanaan pembelajaran matematika pada kurikulum 2013 mengalami perubahan karena materi pembelajaran matematika lebih luas dari pada berbaur dengan tematik (Sulistyani \& Deviana, 2019, hlm, 133-134). Selain itu, pemisahan ini dilakukan di SD Kelas tinggi karena dirasa kajian materinya masih dangkal yang dapat menyebabkan kajian materi matematika yang tidak mendalam (Wiryanto, 2020, hlm. 2). Oleh sebab itu, pemisahan dikaji dari segi waktu dan cakupan materi yang dianggap terlalu sederhana untuk diberikan kepada peserta didik di kelas tinggi.

Pemisahan muatan pelajaran Matematika di kelas tinggi juga memproyeksikan untuk dapat meningkatkan kemampuan matematis peserta didik. Selain itu, Matematika merupakan salah satu mata pelajaran yang dianggap sulit dan jarang diminati oleh siswa, padahal matematika merupakan salah satu mata pelajaran yang memiliki peran penting dalam perkembangan ilmu pengetahuan dan teknologi saat ini. Kondisi kesulitan dalam pembelajaran matematika dapat dipengaruhi oleh sikap negatif, kecemasan, serta rasa tidak percaya diri akan kemampuannya meskipun kemampuan kognitifnya berada pada level normal (Harahap \& Syarifah, 2015, hlm. 21). Selain itu, salah satu penyebab kurangnya minat untuk pembelajaran matematika di antaranya adalah karena pembelajaran cenderung fokus terhadap kognitif dan kurang kontekstual (Harta et al., 2014, hlm. 162). Rendahnya kemampuan matematika peserta didik juga dibuktikan dengan Program for International Students Assessment (PISA) yang menunjukkan bahwa dalam tiga kali tes terakhir, Indonesia masih memiliki kemampuan yang rendah di bawah rata-rata yang ditetapkan (Pratiwi, 2019, hlm, 52). Kondisi ini menunjukkan bahwa perlu adanya peningkatan dalam proses pembelajaran matematika di sekolah dasar sebagai landasan dalam pelaksanaan pembelajaran matematika.

Pada hakikatnya pembelajaran tidak akan lepas dari alat-alat yang biasa digunakan untuk mendorong terjadinya proses pembelajaran, seperti rencana perangkat pembelajaran, bahan ajar, media pembelajaran, LKS dan alat evaluasi untuk mengukur kemampuan siswa. Perangkat pembelajaran merupakan alat-alat kelengkapan yang digunakan untuk memenuhi proses pembelajaran agar mendorong terjadinya pembelajaran (Masitah, 2018, hlm. 41). Salah satu sarana yang dapat dikembangkan untuk meningkatkan kualitas proses pembelajaran adalah bahan ajar. Dalam penggunaannya, bahan ajar perlu memastikan kualitasnya dalam menunjang efektifitas pembelajaran, karena penggunaan bahan ajar linier dengan proses pembelajaran (Cahyadi, 2019, hlm, 36). Penyusunan bahan ajar dapat disesuaikan dengan kebutuhan peserta didik dan pendidik, sehingga bahan ajar dapat dirancang untuk mendorong minat dan memberikan kesempatan belajar secara mandiri dalam pembelajaran sesuai dengan salah satu tujuan dari pendidikan nasional (dalam Omeri, 2015, hlm. 464).

Selain itu, penggunaan bahan ajar selalu diperbarui sesuai dengan kesiapan sekolah dan peserta didik. Penggunaan bahan ajar juga mampu memberikan pengaruh terhadap hasil belajar peserta didik (Pranaja \& Astuti, 2019, hlm. 253). Pernyataan tersebut diperkuat dengan kondisi perkembangan teknologi yang semakin pesat, sehingga pembelajaran perlu disesuaikan dengan pemanfaatan teknologi secara optimal. Fakta lain, peserta didik yang lahir pada tahun 2011-2025 adalah generasi alpha yang cenderung akrab dengan teknologi dan dianggap sebagai generasi yang lebih pintar dari sebelumnya (Fadlurrohim et al., 2020, hlm. 180). Hal ini menjadi tantangan bagi pendidik untuk dapat menghadirkan pembelajaran yang lebih kreatif dan inovatif dengan tetap memperhatikan perkembangan kognitif dan psikologis peserta didik. Pembelajaran juga 
1892 Analisis Kebutuhan Pengembangan E-Modul Materi Bilangan Pecahan di Sekolah Dasar - Elsa Nur Qomalasari, Karlimah, Resa Respati

DOI: https://doi.org/10.31004/edukatif.v3i4.1027

membiasakan siswa untuk mendapatkan keterampilan 4C (Critical Thinking, Communication, Creativity and Collaboration) yang juga berhubungan dengan matematika (Sugiyarti et al., 2018, hlm. 440). Dengan demikian, bahan ajar yang dapat dikembangkan pada bahan ajar yang berbasis elektronik seperti e-modul.

E-modul adalah modul yang diadaptasi dengan memanfaatkan teknologi, karena modul biasanya diidentikkan dengan bahan ajar cetak. Modul adalah bahan ajar yang dirancang secara sistematis pada kurikulum dan dikemas dalam satuan pembelajaran terkecil dan memungkinkan untuk dipelajari secara mandiri dalam waktu tertentu sehingga siswa menguasai kompetensi yang diajarkan (S.Sirate \& Ramadhana, 2017, hlm. 317). Kemandirian belajar ini juga dapat disebut sebagai salah satu faktor internal yang akan mempengaruhi hasil belajar peserta didik (Riyanti, 2021, hlm. 1310). Perbedaan modul dan e-modul lebih mencolok pada perangkat yang digunakannya dimana e-modul mengaplikasikan perangkat lunak dan tambahan media lain untuk melengkapi modul. Oleh karena itu, proses belajar mengajar memerlukan beberapa dukungan seperti e-modul untuk meningkatkan kemampuan peserta didik.

Berdasarkan studi pendahuluan yang telah dilakukan, ternyata penggunaan e-modul masih belum optimal. Meskipun pembelajaran sudah mulai dilaksanakan dalam jaringan belum mampu mendorong pendidik untuk dapat menyediakan media pembelajaran yang dapat diakses oleh peserta didik. Seperti halnya e-modul sebagai bahan ajar yang berpotensi untuk dapat memandirikan peserta didik masih belum digunaan secara merata untuk pembelajaran. e-modul sudah mulai digunakan untuk pembelajaran tematik, namun belum digunakan untuk pembelajaran matematika. Sebuah modul juga dapat disebut sebagai media belajar mandiri karena di dalamnya sudah termuat petunjuk belajar (Suwartaya et al., 2020, hlm. 4). Namun penggunaannya masih belum dikatakan optimal, apalagi pada materi yang dianggap paling sulit baik oleh pendidik maupun oleh peserta didik.

Isi materi yang dianggap sulit dikuasai siswa kelas $\mathrm{V}$ adalah operasi hitung pecahan berpenyebut berbeda. Hal ini termasuk dalam kompetensi dasar keterampilan kognitif. Untuk mengembangkan keterampilan matematika, Yasin \& Enver (2007, hlm. 24) mengatakan bahwa sebelum menjelaskan suatu mata pelajaran baru, konsep-konsep prasyarat dari mata pelajaran tersebut harus diklarifikasi, dan kemudian kemungkinan kesulitan tentang konsep-konsep ini harus ditentukan dan dihilangkan. Untuk pecahan, siswa harus memahami tentang bilangan prima, kelipatan persekutuan terkecil dan jenis pecahan. Hal ini diproyeksikan untuk meningkatkan kemampuan siswa, sehingga e-modul yang disusun perlu memperhatikan kecakapan materi prasyarat dan memberikan kemudahan kepada peserta didik.

Ada beberapa penelitian terkait modul yang telah diteliti oleh beberapa peneliti. Demikian pula pengembangan e-modul telah diteliti oleh beberapa peneliti, salah satunya hasil penelitian Suarsana \& Mahayukti (2013) yang menunjukkan bahwa penggunaan e-modul dalam meningkatkan berpikir kritis dan hasil belajar siswa mengalami peningkatan dari rata-rata sebesar 27,6 (sedang) pada siklus I menjadi 3,14 (tinggi) pada siklus II dan nilai e-modul 75,5. Selain itu, modul juga telah dikembangkan oleh Rahmiyati \& Darmaji (2014) dengan judul penelitian "Pengembangan Modul Elektronik dengan Pendekatan Ilmiah pada Pembahasan Pokok Hukum Termodinamika SMA/MA Kelas XI" menunjukkan bahwa persentase elektronik modul adalah 75,23 dan dikategorikan sangat baik untuk digunakan oleh siswa. Berdasarkan penelitian ini, ini merupakan peluang untuk dapat menggunakan e-modul untuk bilangan pecahan. Jadi, peneliti harus menentukan bagaimana kebutuhan e-modul untuk proses pembelajaran.

Analisis kebutuhan ini bertujuan untuk mengetahui bagaimana pengembangan kebutuhan modul pembelajaran dengan materi bilangan pecahan untuk kelas V di Sekolah Dasar. Analisis dilakukan karena berbagai alasan. Alasan pertama, pembelajaran perlu memberikan pembiasaan akan tuntutan keterampilan pemecaan salah dan berpikir tingkat tinggi. Alasan kedua, perlunya bahan ajar yang dimodifikasi dengan pemanfaatan teknologi sebagai Generasi Alpha dan untukpembiasaan keterampilan $4 C$ 's skills. Alasan ketiga, perlunya bahan ajar yang mendukung perkembangan dan pertumbuhan kognitif dan psikologis sesuai tugas perkembangannya. Analisis kebutuhan yang dilakukan meliputi analisis kurikulum, peserta didik, materi 
1893 Analisis Kebutuhan Pengembangan E-Modul Materi Bilangan Pecahan di Sekolah Dasar - Elsa Nur Qomalasari, Karlimah, Resa Respati

DOI: https://doi.org/10.31004/edukatif.v3i4.1027

bilangan pecahan dan analisis kondisi sekolah. Dengan demikian, analisis ini dapat digunakan sebagai dasar untuk mengembangkan e-modul materi bilangan pecahan yang sesuai dengan kebutuhan di Sekolah Dasar dan dapat mengimplementasikan perkembangan teknologi dalam proses pembelajaran.

\section{METODE PENELITIAN}

Penelitian ini menggunakan metode penelitian kualitatif. Metode penelitian kualitatif sering disebut penelitian naturalistik karena penelitian dilakukan dalam kondisi alamiah (Sugiyono, 2019, hlm. 17). Oleh karena itu, jenis penelitian pada penelitian ini menggunakan deskriptif kualitatif. Metode pendekatan deskriptif kualitatif adalah suatu metode pengolahan data dengan menganalisis faktor-faktor yang berhubungan dengan objek penelitian dengan menyajikan data secara lebih mendalam pada objek penelitian (Prabowo \& Heriyanto, 2013, hlm. 5).

Penelitian dilakukan pada bulan Maret-Mei 2021, kurang lebih tiga bulan. Sedangkan untuk lokasi penelitian, peneliti menetapkan tiga Sekolah Dasar yang ditentukan berdasarkan akreditasi, prestasi, wilayah, dan kemudahan akses bagi peneliti. Maka peneliti memilih SDN 1 Dukuhmaja, SDN 2 Dukuhmaja dan SDN 1 Luragunglandeuh, Kabupaten Kuningan. Kondisi sekolah dapat mempresentasikan perbedaan kondisi dengan instrument penelitian yang sama.

Dalam penelitian kualitatif, populasi dan sampel memiliki istilah yang berbeda. Populasi dalam penelitian kualitatif disebut situasi sosial yang meliputi tempat, pelaku, dan kegiatan yang saling berkaitan secara sinergis. Teknik pengambilan sampel menggunakan teknik purposive sampling. Peneliti menentukan kriteria sampel dalam mengumpulkan data. Berdasarkan jenis data yang akan dikumpulkan, peneliti menentukan objek yang dijadikan sumber data dalam penelitian yang berupa manusia, dokumen, objek dan sebagainya. Sumber data dan informan yang ditentukan dalam penelitian ini adalah guru kelas V, peserta didik, sekolah, dan dokumen pendukung lainnya. Guru sebagai narasumber wawancara, peserta didik untuk melihat kondisi dalam proses pembelajaran, sekolah sebagai narasumber untuk melihat kondisi penunjang pembelajaran dan peneliti akan melihat dokumen-dokumen yang ada untuk menjadi data pendukung dalam penelitian guna mempertajam data dalam penelitian.

Data kualitatif diperoleh dari proses penelitian dengan teknik pengumpulan data menggunakan wawancara, observasi dan studi dokumentasi. Teknik analisis data yang digunakan adalah triangulasi data. Tahap ini akan selesai apabila telah ditemukan data yang jenuh dari tiga teknik pengumpulan data yang sedang dilakukan. Pengolahan data dimulai dengan pengumpulan semua teknik pengumpulan data. Kemudian, data disajikan untuk menggambarkan hal-hal yang sesuai dengan kebutuhan peneliti. Dalam proses penyajian data akan dilakukan reduksi data sehingga peneliti mampu menarik kesimpulan dari data yang telah diolah. Wawancara yang dilakukan bertujuan untuk dapat mengetahui pola pikir narasumber dari kondisi bahan ajar. Observasi bertujuan untuk mengetahui informasi yang tidak terbatas pada hasil wawancara dan studi dokumentasi. Hal ini juga menjadi data pendukung dari wawancara. Dan, studi dokumentasi akan diperlukan untuk mempertajam analisis penelitian terkait informasi yang bertujuan untuk meningkatkan kemampuan siswa.

Tahap wawancara, peneliti menggunakan tipe wawancara semi terstruktur dengan tujuan agar percakapan dapat lebih mewakili data dengan tujuan dapat menggambarkan pola pikir instrumen. Berikut kisikisi panduan wawancara:

Tabel 1. Kisi-kisi Wawancara

\begin{tabular}{|c|c|c|c|}
\hline $\begin{array}{c}\text { Sumber } \\
\text { Data }\end{array}$ & Aspek yang Diamati & Nomor Butir & Jumlah \\
\hline Guru & 1. Perangkat Pembelajaran & 1,2 & 2 \\
\hline
\end{tabular}


1894 Analisis Kebutuhan Pengembangan E-Modul Materi Bilangan Pecahan di Sekolah Dasar - Elsa Nur Qomalasari, Karlimah, Resa Respati

DOI: https://doi.org/10.31004/edukatif.v3i4.1027

\begin{tabular}{llcc}
\hline 2. & Penyusunan Bahan Ajar & $3,4,5,6$ & 4 \\
\cline { 2 - 4 } 3. & $\begin{array}{l}\text { Pembelajaran Matematika Bilangan } \\
\text { Pecahan di Kelas V SD }\end{array}$ & $7,8,9,10,11,12$, & 6 \\
\cline { 2 - 4 } & & 13.14 & 2 \\
\hline 4. & Kebutuhan Media & $15,16,17,18,19,20$ & 6 \\
\hline \multicolumn{2}{c}{ Ketersediaan E-Modul } & & $\mathbf{2 0}$ \\
\hline
\end{tabular}

Kemudian dilakukan observasi untuk mendapatkan kondisi fisik dan non fisik di lokasi penelitian. Berikut ini adalah kisi-kisi panduan observasi:

Tabel 2. Kisi-kisi Observasi

\begin{tabular}{llc}
\hline No & \multicolumn{1}{c}{ Aspek yang Diamati } & Jumlah \\
\hline 1. & Kondisi Sekolah dan Sekitarnya & 2 \\
\hline 2. & Kondisi Peserta Didik & 4 \\
\hline 3. & Bahan Ajar dalam Pembelajaran & 6 \\
\hline 4. & Media Pembelajaran Matematika di SD & 2 \\
\hline 5. & Proses Pembelajaran & 6 \\
\hline & $\quad$ Jumlah & $\mathbf{2 0}$
\end{tabular}

Dalam teknik studi dokumentasi, peneliti mengumpulkan dokumen-dokumen tercetak dan non-cetak yang berkaitan dengan subjek penelitian. Data yang diperoleh dalam studi dokumentasi kemudian digunakan sebagai alat untuk memeriksa kesesuaian data yang diperoleh dari wawancara dan observasi sebagai teknik triangulasi data untuk memperoleh data yang valid. Proses triangulasi data akan terus dilakukan sampai ditemukan data yang jenuh dari ketiga proses teknik analisis data kualitatif. Berikut kisi-kisi panduan studi dokumentasi:

Tabel 3. Kisi-kisi Studi Dokumentasi

\begin{tabular}{lll}
\hline \multicolumn{1}{c}{ Sumber Data } & \multicolumn{1}{c}{ Aspek yang Diamati } \\
\hline Dokumen Administrasi & 1. & Silabus Mata Pelajaran Matematika \\
\cline { 2 - 3 } Sekolah & 2. & Daftar inventaris perangkat pembelajaran \\
\cline { 2 - 3 } & 3. & Dokumen hasil belajar materi bilangan pecahan \\
\cline { 2 - 3 } & 4. & Dokumen hasil belajar mata pelajaran matematika \\
\cline { 2 - 3 } & 5. & Dokumen bahan ajar cetak bilangan pecahan \\
\cline { 2 - 3 } & 6. & Dokumen bahan ajar non-cetak bilangan pecahan \\
\cline { 2 - 3 } & 7. & Kriteria Ketuntasan Minimum (KKM) \\
\hline
\end{tabular}

Peneliti menggunakan metode deskriptif kualitatif untuk menganalisis data. Data yang diperoleh dari wawancara diolah dengan analisis deskriptif kualitatif dengan cara mendeskripsikan secara keseluruhan. Data wawancara merupakan sumber utama dalam menjawab rumusan masalah dalam penelitian. Analisis data diawali dengan hasil wawancara yang disimak kembali dari rekaman, kemudian dituliskan seluruhnya. Setelah itu, peneliti mengabstraksikan hasil wawancara dengan fokus pada hal-hal yang berkaitan dengan penelitian dan mengabaikan informasi yang tidak sesuai. Dengan demikian, data wawancara tersebut akan dikonfirmasi dengan data observasi dan studi dokumentasi.

\section{HASIL DAN PEMBAHASAN PENELITIAN}

Berdasarkan hasil wawancara, peneliti menemukan fakta bahwa penyediaan perangkat pembelajaran secara administratif cenderung lengkap mulai dari kurikulum, silabus, rencana pelaksanaan pembelajaran, program tahunan, program semester, bahan ajar, media pembelajaran, dan perangkat evaluasi. Penyediaan semua perangkat pembelajaran ini didanai dari Biaya Operasional Sekolah (BOS). Salah satu perangkat pembelajaran yaitu bahan ajar yang disediakan sesuai dengan kebutuhan dan kondisi peserta didik. Pendidik menyatakan bahwa semua bahan ajar penyediaan didominasi oleh Kelompok Kerja Guru (KKG) di setiap konten pelajaran, seperti matematika. Dalam penggunaan bahan ajar, para pendidik seringkali memperbaharui 
1895 Analisis Kebutuhan Pengembangan E-Modul Materi Bilangan Pecahan di Sekolah Dasar - Elsa Nur Qomalasari, Karlimah, Resa Respati

DOI: https://doi.org/10.31004/edukatif.v3i4.1027

dan mencari sumber lain, baik dari internet maupun buku cetak yang disediakan oleh sekolahnya. Pemanfaatan ini diproyeksikan untuk digunakan dalam proses pembelajaran sesuai dengan tujuannya.

Proses pembelajaran matematika di sekolah dasar sedikit berbeda dengan mata pelajaran lainnya. Penerapan kurikulum 2013 memproyeksikan konten matematika untuk dipadukan dalam pembelajaran tematik. Namun, pada tahun 2016 pelaksanaan matematika dipisahkan untuk kelas tinggi, untuk kelas 4, 5, dan 6. Berdasarkan hasil wawancara, siswa memiliki berbagai kemampuan dalam proses pembelajaran matematika. Ada peserta didik yang sangat baik, sedang, dan bahkan sangat lemah dalam matematika. Namun, kesulitan yang disebutkan di setiap lokasi penelitian menyatakan bahwa peserta didik sering kesulitan memahami beberapa kalimat dalam pertanyaan cerita, seperti halnya pemecahan masalah. Selain itu, mereka belum dibiasakan untuk memiliki pembelajaran berpikir tingkat tinggi, sehingga siswa memiliki kemampuan berpikir tingkat rendah hingga menengah. Hal ini juga sesuai dengan hasil penelitian Sulistyani \& Deviana, (2019, hlm. 140) bahwa bahan ajar yang dikembangkan perlu memuat latihan keterampilan berpikir tingkat tinggi (HOTS). Tentunya penyusunan bahan ajar dengan memperhatikan pembiasaan berpikir tingkat tinggi agar dapat melatih hingga terbiasa untuk masuk ke dalam level berpikir tingkat tinggi.

Hal ini disebabkan oleh berbagai faktor, antara lain (1) latar belakang orang tua/wali dari segi pendidikan, ekonomi, dan sosial; (2)lingkungan masyarakat yang kurang mendukung proses pembelajaran di luar sekolah; (3)kurangnya perhatian dan bimbingan bagi peserta diidk; (4) rendahnya tingkat fokus peserta didik; (5) keterbatasan media pembelajaran, dan (6) rendahnya kemandirian peserta didik dalam belajar. Karena kondisi ini, pendidik hanya memberikan materi dasar untuk mencapai kompetensi dasar dari kurikulum.

Berdasarkan faktor-faktor yang menunjukkan rendahnya kemampuan siswa dalam matematika, salah satunya adalah terbatasnya media yang membantu peserta didik lebih mudah dalam belajar. Dijelaskan pula oleh masing-masing pendidik, bahwa penggunaan media pembelajaran bukanlah prioritas. Menurut guru kelas V SDN 2 Dukuhmaja, media yang digunakan sudah cukup mewakili bentuk nyata dari materi bilangan pecahan yang diajarkan meskipun hanya mengunakan barang seadanya di sekeliling peserta didik. Sedangkan menurut para pendidik di dua SD lainnya, mereka lebih memilih menggunakan media dari internet atau membuatnya sendiri. Padahal ketersediaan media/ alat peraga materi bilangan pecahan cenderung lengkap di SDN 1 Luragunglandeuh sehingga berpeluang untuk dapat meningkatkan kemampuan belajar siswa. Dalam proses pembelajaran matematika, pendidik lebih memilih untuk memilih bertemu dalam kelompok kecil, dan mengajar satu per satu, padahal memanfaatkan media adalah salah satu solusi yang dapat digunakan dalam proses pengajaran.

Keterbatasan media pembelajaran di lokasi penelitian menunjukkan bahwa terdapat kebutuhan media pembelajaran sesuai dengan kondisi dan kebutuhan sekolah dan siswa. Para pendidik merasa begitu pasrah karena pandemi yang telah membuat masalah kompleks baru bagi proses pembelajaran. Khususnya untuk media pembelajaran yang dapat digunakan oleh pendidik dan peserta didik. Kondisi ini ditegaskan oleh pernyataan pendidik dalam proses wawancara dalam hal kebutuhan akan media yang mudah dan murah. Dalam konteks ini, salah satu media yang dapat digunakan adalah media elektronik (e-modul). Namun, setiap sekolah di lokasi penelitian belum mengoptimalkan keberadaan dan pemanfaatan e-modul ini. Hanya ditemukan satu sekolah yang sudah mulai menggunakan e-modul untuk memberikan tugas terstruktur dalam waktu tertentu. Smenetara itu, menurut penelitian sebelumnya Nurdyansyah \& Mutala'liah (2015,hlm. 14) modul dapat dimanfaatkan sebagai alternatif untuk proses pembelajaran. Meskipun demikian, pemanfaatannya masih belum optimal dan belum tersedianya materi bilangan pecahan bagi siswa kelas V SD.

Dengan demikian, berdasarkan hasil wawancara menunjukkan bahwa persyaratan administrasi sudah lengkap. Namun, siswa belum terbiasa dengan kemampuan berpikir tingkat tinggi sebagai kemampuan mereka, dan mereka perlu menggunakan media pembelajaran untuk membantu mereka meningkatkannya. Kondisi ini dapat terjadi karena penyediaan media pembelajaran tidak menjadi prioritas dan keterbatasan dana 
1896 Analisis Kebutuhan Pengembangan E-Modul Materi Bilangan Pecahan di Sekolah Dasar - Elsa Nur Qomalasari, Karlimah, Resa Respati

DOI: https://doi.org/10.31004/edukatif.v3i4.1027

BOS, serta rendahnya kreativitas pendidik dalam mengembangkan perangkat pembelajaran khususnya media pembelajaran.

Hasil wawancara akan dikonfirmasikan dengan hasil observasi. Kondisi sekolah dan sekitarnya, setelah mengamati secara langsung peneliti menemukan fakta bahwa sekolah tersebut memiliki kenyamanan untuk kelangsungan proses pembelajaran baik dari segi lokasi, sarana prasarana maupun keindahannya. Bahkan, di masa pandemi, ada beberapa ruangan yang sengaja diperbaiki untuk pelaksanaan pembelajaran tatap muka. Namun dari kondisi tersebut belum ada ruangan khusus yang disediakan untuk menyimpan media pembelajaran. Oleh karena itu, perangkat pembelajaran yang dibutuhkan oleh setiap tingkatan kelas disimpan di meja pendidik di ruang pendidik, dan terkadang disimpan di ruang kelas, ruang perpustakaan, dan ruang komputer. Hal tersebut membuat perangkat pembelajaran di setiap sekolah tidak terpelihara dengan baik dan menunjukkan kurangnya perhatian dalam penggunaannya pada mata pelajaran yang bersangkutan. Selain itu, pendidik juga cenderung kurang kreatif untuk dapat menggunakan media sesuai dengan kebutuhan dan kesenangan peserta didik.

Ketersediaan media pembelajaran memiliki keterbatasan di semua lokasi penelitian, sedangkan di SDN 1 Luragunglandeuh terdapat tiga alat peraga yang membantu proses pembelajaran, dan SD lainnya tidak tersedia. Alat peraga berikut tersedia dalam bentuk (1) Alat Peraga Matematika Pemula untuk Sekolah Dasar: Akselerasi Pemahaman dalam Pembelajaran Matematika; (2) Persentase/Pecahan, Diagram Desimal, dan (3) Permainan Pecahan Paket Alat Bantu Ajar Matematika: Pecahan Persegi, Pecahan Lingkaran, Model Statistik, Blok Logika. Alat peraga ini disimpan di ruang komputer dan jarang digunakan untuk pembelajaran, terlihat dari kondisinya yang baik namun tidak terawat karena berdebu. Pendidik jarang menggunakannya untuk di kelas secara langsung.

Namun, pembelajaran online membuat media yang tersedia atau alat peraga juga terjadi disfungsi. Pendidik memilih untuk berselancar di internet untuk mendapatkan sumber belajar bagi peserta didik. Bahkan dalam pembelajaran matematika, pendidik menggunakan video dari Youtube dan juga untuk beberapa kondisi yang memungkinkan pertemuan, pendidik berusaha mengadakan pembelajaran di rumah dengan jumlah peserta didik kurang dari lima orang. Perangkat yang digunakan juga terbatas pada buku ajar cetak milik peserta didik yang sengaja disediakan oleh pihak sekolah. Tidak ada jenis bahan ajar dan media lain untuk mendukung pembelajaran matematika pecahan, padahal pembelajaran membutuhkan alat bantu untuk membantu siswa.

Proses pembelajaran di masa pandemi mendorong peserta didik untuk dapat mengakses perangkat elektronik untuk dapat mengikuti pembelajaran. Hampir setiap anak kelas V di lokasi penelitian telah diberikan perangkat hak milik pribadi, namun ada beberapa peserta didik yang masih bersama orang tuanya karena berbagai faktor. Seperti proses pembelajaran dengan menggunakan grup WhatsApp, peserta didik dapat mengakses perangkat untuk menyelesaikan tugas yang diberikan oleh guru. Namun, dalam proses pembelajaran matematika, siswa terlihat kurang aktif dalam merespon setiap instruksi dalam pembelajaran. Hal ini berkaitan dengan berbagai kemampuan peserta didik dalam matematika.

Dengan demikian, temuan dalam proses observasi ini menunjukkan bahwa peserta didik memiliki respon yang sedikit berbeda dari mata pelajaran lain. Peserta didik menunjukkan partisipasi yang kurang aktif dalam proses pembelajaran. Hal ini juga didukung oleh keterbatasan bahan ajar dan media yang mereka gunakan selama proses pembelajaran. Seperti diketahui, proses pembelajaran perlu memfasilitasi peserta didik sebagai pembelajar dari audio, pembelajar dari video atau kebutuhan untuk berlatih. Bahkan pembelajaran sudah mulai menggunakan hybrid learning sehingga perangkat pembelajaran juga perlu dimutakhirkan sesuai dengan kebutuhan pelaksanaan proses pembelajaran. Oleh karena itu, perlu dihasilkan media yang memfasilitasi pembelajaran secara menyeluruh untuk dapat meningkatkan respon peserta didik. 
1897 Analisis Kebutuhan Pengembangan E-Modul Materi Bilangan Pecahan di Sekolah Dasar - Elsa Nur Qomalasari, Karlimah, Resa Respati

DOI: https://doi.org/10.31004/edukatif.v3i4.1027

Kemudian pada tahap studi dokumentasi ini terdapat dokumen-dokumen yang tersedia di sekolah maupun di luar sekolah atau internet untuk mengetahui bentuk materi e-modul pada pecahan di lapangan. Berikut adalah tabel analisis dokumen di sekolah:

Tabel 4. Hasil Studi Dokumentasi

\begin{tabular}{llccc}
\hline No. & \multicolumn{1}{c}{ Aspek yang Diamati } & $\begin{array}{c}\text { SDN 1 } \\
\text { Dukuhmaja }\end{array}$ & $\begin{array}{c}\text { SDN 2 } \\
\text { Dukuhmaja }\end{array}$ & $\begin{array}{c}\text { SDN 1 } \\
\text { Luragunglandeuh }\end{array}$ \\
\hline 1. & Silabus Mata Pelajaran Matematika & $\sqrt{ }$ & $\sqrt{ }$ & $\sqrt{ }$ \\
\hline 2. & $\begin{array}{l}\text { Daftar inventaris perangkat } \\
\text { pembelajaran }\end{array}$ & $\sqrt{ }$ & $\sqrt{ }$ & $\sqrt{ }$ \\
\hline 3. & $\begin{array}{l}\text { Dokumen hasil belajar materi } \\
\text { bilangan pecahan }\end{array}$ & $\sqrt{ }$ & $\sqrt{ }$ & $\sqrt{ }$ \\
\hline 4. & $\begin{array}{l}\text { Dokumen hasil belajar mata } \\
\text { pelajaran matematika }\end{array}$ & $\sqrt{ }$ & $\sqrt{ }$ & - \\
\hline 5. & $\begin{array}{l}\text { Dokumen bahan ajar cetak bilangan } \\
\text { pecahan }\end{array}$ & $\sqrt{ }$ & $\sqrt{ }$ & $\sqrt{ }$ \\
\hline 6. & $\begin{array}{l}\text { Dokumen bahan ajar non-cetak } \\
\text { bilangan pecahan }\end{array}$ & - & - & \\
\hline 7. & $\begin{array}{l}\text { Kriteria Ketuntasan Minimum } \\
\text { (KKM) }\end{array}$ & $\sqrt{ }$ & $\sqrt{ }$ & \\
\hline
\end{tabular}

Berdasarkan tabel 4 dijelaskan bahwa dokumen di setiap sekolah cenderung lengkap, namun belum tersedia dokumen non-cetak untuk bahan ajar pada konten bilangan pecahan. Pada silabus matematika, kompetensi dasar hanya dijelaskan paling banyak pada dua indikator dengan kata kerja operasional yang sama seperti pada kompetensi dasar. Selain itu, indikator tidak dijabarkan dalam tiga kategori indikator yaitu indikator kunci, pendukung dan pengayaan yang akan membantu pendidik dan siswa dalam menguasai materi yang akan dipelajari. Hal ini juga berkaitan dengan bagaimana pembelajaran matematika harus memberikan prasyarat untuk meminimalisir permasalahan yang dapat muncul pada fokus materi pembelajaran yang akan dipelajari. Oleh karena itu, kelengkapan administrasi belum menunjukkan kualitas proses pembelajaran yang baik sehingga pembiasaan kemampuan berpikir tingkat tinggi juga belum termasuk. Padahal, pembiasaan kemampuan tersebut sudah menjadi tuntutan dari kurikulum.

Adapun daftar inventaris alat pembelajaran, belum banyak pendidik yang mengetahui tentang media pembelajaran dan alat peraga yang dapat digunakan untuk pembelajaran. Oleh karena itu, perangkat pembelajaran yang ada di sekolah cenderung kurang terpelihara dan kurang memadai karena tidak layak. Sebenarnya hal ini seharusnya menjadi dorongan bagi pendidik untuk dapat memanfaatkan perangkat pembelajaran yang sesuai dengan kebutuhan pemenuhan kompetensi dasar. Namun hal ini terus terjadi karena pendidik hanya mengutamakan kenyamanan buku cetak dan media murah tanpa memperhatikan kemudahan yang dapat diperoleh siswa dalam hal tugas perkembangannya.

Berdasarkan hasil wawancara, peserta didik memiliki berbagai kemampuan, baik dalam pembelajaran tematik maupun dalam pembelajaran matematika. Hal ini dibuktikan dengan hasil belajar peserta didik yang menunjukkan keragaman. Pendidik mengeluhkan proses penilaian yang dinilai kurang objektif karena proses pembelajaran tidak diawasi secara langsung oleh mereka sehingga nilai yang diperoleh peserta didik belum tentu hasil sendiri. Namun, masih ada peserta didik yang membutuhkan bimbingan khusus untuk dapat mencapai tujuan pembelajaran yang telah ditetapkan. Salah satu cara yang dapat direncanakan adalah dengan mendorong peserta didik memiliki kemandirian untuk belajar.

Peserta didik mempelajari materi sesuai dengan bimbingan dan petunjuk instruksional dari pendidik. Salah satunya adalah penggunaan bahan ajar Matematika yang dapat digunakan dalam bentuk buku cetak. Kondisi buku ajar di sekolah sudah cukup memenuhi kriteria bahan ajar bagi siswa. Namun, bahan ajar juga 
1898 Analisis Kebutuhan Pengembangan E-Modul Materi Bilangan Pecahan di Sekolah Dasar - Elsa Nur Qomalasari, Karlimah, Resa Respati

DOI: https://doi.org/10.31004/edukatif.v3i4.1027

dinilai kurang optimal karena masing-masing sekolah mengutamakan pengisian LKS khusus yang berkaitan langsung dengan setiap tema yang dicanangkan oleh Pusat Kurikulum dan Perbukuan (Puskurbuk). Oleh karena itu, buku teks cetak juga tersimpan rapi di setiap kelas. Menariknya, salah satu pendidik dari kelas V ini memiliki banyak sumber belajar yang menjadi acuan dalam pembelajaran materi Matematika, begitu juga materi bilangan pecahan. Namun, bahan ajar dalam bentuk non cetak belum banyak diproduksi dan disediakan di sekolah, padahal perkembangan teknologi semakin canggih.

Berdasarkan kondisi tersebut, pendidik perlu meningkatkan kemampuannya agar dapat mendorong kemampuan siswa dalam memahami materi bilangan pecahan. Karena berdasarkan hasil wawancara, materi ini merupakan materi yang paling sulit dikuasai dibandingkan materi lainnya. Oleh karena itu, pendidik perlu melakukan analisis yang lebih mendalam dalam menentukan perangkat pembelajaran yang sesuai dengan kondisi peserta didik, seperti kemandirian belajarnya.

Salah satu bahan ajar yang dapat digunakan adalah e-modul agar siswa dimudahkan dalam mempelajari materi dengan bimbingan terbatas dari pendidik. Namun, pendidik tidak bertindak aktif untuk dapat memberikan hal tersebut. Ketika pertanyaan tentang e-modul diajukan kepada pendidik, mereka secara bersamaan menjawab dengan pernyataan yang hampir sama, dimana mereka menyatakan bahwa penyediaan e-modul memang baik untuk digunakan oleh siswa. Namun, pendidik belum pernah membuatnya sehingga menggunakan buku cetak yang ada adalah pilihan yang paling tepat menurut mereka. Namun, mereka juga menambahkan bahwa akan lebih praktis digunakan dalam kondisi pembelajaran yang terbatas. Seperti di SDN 2 Dukuhmaja, ada rencana untuk menggunakan e-book, namun mahal dan perlu menyertakan anggaran BOS. Bahkan untuk membuat e-book ada platform gratis yang bisa digunakan.

Penyediaan media digital ternyata menjadi pertimbangan bagi setiap sekolah, namun terbentur dengan kondisi biaya yang tidak bisa tiba-tiba dikeluarkan. Karena anggaran dari dana BOS perlu dirancang di awal tahun dan pengeluarannya sesuai dengan rencana. Sementara itu, pendidik juga menyadari rendahnya kemampuan yang dimiliki untuk dapat memberikan proses pembelajaran yang sesuai dengan karakteristik peserta didik, baik dari segi karakter generasi, kognitif maupun psikososial dalam pembelajaran online. Bahkan, tugas yang diberikan melalui WhatsApp tidak menunjukkan kualitas proses pembelajaran yang berhasil. Oleh karena itu, pendidik perlu meningkatkan kemampuannya dalam menyediakan media yang sesuai dengan kebutuhan pembelajaran yang sesuai dengan situasi dan kondisi.

Pendidik perlu menyediakan media yang sesuai dengan kebutuhannya, serta media yang mendorong peserta didik untuk dapat belajar secara mandiri, sehingga peserta didik dapat bertanggung jawab atas tugasnya dalam belajar. Tidak hanya untuk mengerjakan tugas, tetapi juga dapat membantu siswa untuk meningkatkan minat belajar matematika. Hal ini memang menjadi tantangan tersendiri bagi pendidik, namun pencapaian kompetensi ini tentunya untuk dapat meningkatkan kemampuan peserta didik dalam memecahkan masalah hidupnya khususnya pada materi pecahan. Peserta didik sering menganggap belajar matematika itu sulit, padahal mereka belum mempelajarinya. Paradigma tersebut perlu diubah dengan menghadirkan proses pembelajaran yang tepat.

Penelitian ini dilakukan di sekolah dengan akreditasi berbeda dengan tujuan menghadirkan karakteristik yang beragam, namun pada kenyataannya kondisi sekolah di situasi pandemi mengindikasikan kesamaan akan gagapnya penggunaan teknologi dan rendahnya kreativitas dari pendidik untuk menghadirkan bahan ajar yang adaptif. Hal ini menunjukkan keterbatasan temuan pada penelitian yang dilakukan, baik dari segi kondisi pembelajaran yang diharapkan memiliki keragaman dan terbatasnya informasi yang diberikan oleh informan sebagai sumber data. Oleh sebab itu, peneliti mengolah data wawancara seluruhnya dengan kondisi yang hampir sama, kemudian terdapat sedikit perbedaan dalam hal media yang tersedia di sekolah dengan akreditasi A.

Penelitian-penelitian sebelumnya telah memperjelaskan perihal penggunaan e-modul yang dapat meningkatkan keefektivitasan dan menunjukkan kepraktisannya pada materi tertentu. Kondisi analisis 
1899 Analisis Kebutuhan Pengembangan E-Modul Materi Bilangan Pecahan di Sekolah Dasar - Elsa Nur Qomalasari, Karlimah, Resa Respati

DOI: https://doi.org/10.31004/edukatif.v3i4.1027

kebutuhan e-modul ini juga telah diteliti oleh Purwoko et al., (2020, hlm. 6) yang menunjukkan bahwa tidak selamanya peserta didik belajar dengan menggunakan bahan ajar yang ada pada umumnya sehingga memerlukan bahan ajar yang dinilai menyenangkan seperti modul berbasis elektronik. Hal ini memproyeksikan agar asumsi sulitnya pembelajaran matematika dapat perlahan menghilang dan menganggap matematika sebagai muatan pelajaran yang menyenangkan. Meskipun pada penelitian ini mengambil materi yang dinilai paling sulit dikuasai oleh peserta didik. Hal ini didukung oleh penelitian Vitrianingsih et al., (2021, hlm, 35) yang menunjukkan kebutuhan e-modul pada materi yang dinilai sulit pada materi Fisika. Oleh sebab itu, kebutuhan e-modul dapat menjadi alternatif dalam pembelajaran meskipun pada materi tersulit.

Penyediaan e-modul ini merupakan pilihan yang dapat digunakan untuk proses pembelajaran dengan ciri mampu menjelaskan secara mandiri, hal ini membantu siswa untuk dapat belajar secara mandiri. Karena di dalam e-modul terdapat petunjuk pembelajaran dan uraian lengkap materi yang ditujukan kepada sasaran. Pendidik dapat mengembangkan e-modul untuk digunakan dengan pertemuan terbatas agar memudahkan proses pembelajaran. Analisis kebutuhan e-modul ini akan berdampak pada keberlangsungan proses pembelajaran dan minat peserta didik terhadap pembelajaran matematika. Berdasarkan hal tersebut, asumsi sulitnya belajar matematika perlahan menghilang dengan menimbang kepentingan akan kehadirannya sebagai dasar dalam perkembangan teknologi. Selain itu, pengembangan e-modul juga dapat memproyeksikan akan pemanfaatan teknologi dalam menyusun sebuah bahan ajar sebagai perangkat pembelajaran. E-modul juga dapat menjadi media yang dapat digunakan untuk meningkatkan hasil belajar dari peserta didik.

\section{KESIMPULAN}

E-modul merupakan salah satu bentuk bahan ajar yang dapat digunakan dalam proses pembelajaran materi bilangan pecahan yang dianggap sulit untuk dikuasai oleh peserta didik di SD. Keterbatasan penyediaan bahan ajar mendorong perlunya pengembangan atau pembaharuan dalam penggunaan bahan ajar yang ada. Selain itu, Pengembangan perlu memperhatikan karakteristik generasi, perkembangan teknologi, kognitif, psikologis serta pembiasaan berpikir tingkat tinggi dan kemampuan pemecahan masalah peserta didik. Dengan karakteristik self-explanation dapat membuat peserta didik dapat belajar sendiri, dimana hal ini sesuai dengan kondisi pembelajaran jarak jauh saat ini. Oleh karena itu, perlu adanya pengembangan e-modul pada materi bilangan pecahan di SD dengan tujuan meningkatkan kemampuan hasil belajar peserta didik dan membuat pembelajaran matematika menjadi lebih menyenangkan.

\section{DAFTAR PUSTAKA}

Badaruddin, Kadir, \& Anggo, M. (2016). Analisis Kesalahan Dalam Menyelesaikan Soal-Soal Operasi Hitung Pecahan Pada Siswa Kelas Vii Smp Negeri 10 Kendari. Jurnal Penelitian Pendidikan Matematika, 5(1), 99-113.

Cahyadi, R. A. H. (2019). Pengembangan Bahan Ajar Berbasis Addie Model. Halaqa: Islamic Education Journal, 3(1), 35. Https://Doi.Org/10.21070/Halaqa.V3i1.2124

Fadlurrohim, I., Husein, A., Yulia, L., Wibowo, H., \& Raharjo, S. T. (2020). Memahami Perkembangan Anak Generasi Alfa Di Era Industri 4.0. Focus: Jurnal Pekerjaan Sosial, 2(2), 178. Https://Doi.Org/10.24198/Focus.V2i2.26235

Harahap, D. H., \& Syarifah, R. (2015). Jurnal-Psikologi-Vol-11-2015c-.Pdf(Pp. 20-30).

Harta, I., Tenggara, S., \& Kartasura, P. (2014). Pengembangan Modul Pembelajaran Untuk Meningkatkan Pemahaman Konsep Dan Minat Smp. Pengembangan Modul Pembelajaran Untuk Meningkatkan Pemahaman Konsep Dan Minat Smp, 9(2), 161-174. Https://Doi.Org/10.21831/Pg.V9i2.9077

Masitah. (2018). Pengembangan Perangkat Pembelajaran Untuk Memfasilitasi Guru Menumbuhkan Rasa 
1900 Analisis Kebutuhan Pengembangan E-Modul Materi Bilangan Pecahan di Sekolah Dasar - Elsa Nur Qomalasari, Karlimah, Resa Respati

DOI: https://doi.org/10.31004/edukatif.v3i4.1027

Tangung Jawab Siswa Sd Terhadap Masalah Banjir. Proceeding Biology Education Conference, 15(1), $40-44$.

Nurdyansyah, \& Mutala'liah, N. (2015). Pengembangan Bahan Ajar Modul Ilmu Pengetahuan Alambagi Siswa Kelas Iv Sekolah Dasar. Program Studi Pendidikan Guru Madrasa Ibtida’iyah Fakultas Agama Islam Universitas Muhammadiyah Sidoarjo, 41(20), 1-15.

Omeri, N. (2015). Pentingnya Pendidikan Karakter Dalam Dunia Pendidikan. Manajer Pendidikan, 9(Manager Pendidikan), 464-468.

Prabowo, A., \& Heriyanto. (2013). Analisis Pemanfaatan Buku Elektronik (E-Book) Oleh Pemustaka Di Perpustakaan Sma Negeri 1 Semarang [Analysis Of The Utilization Of Electronic Books (E-Books) By Pemustaka At The Sma Negeri 1 Semarang Library]. Jurnal Ilmu Perpustakaan, 2(2), 1-9. Https://Ejournal3.Undip.Ac.Id/Index.Php/Jip/Article/View/3123

Pranaja, A., \& Astuti, Y. (2019). Edukatif: Jurnal Ilmu Pendidikan. Jurnal Ilmu Pendidikan, 1(3), 294-302. Https://Edukatif.Org/Index.Php/Edukatif/Index

Pratiwi, I. (2019). Efek Program Pisa Terhadap Kurikulum Di Indonesia. Jurnal Pendidikan Dan Kebudayaan, 4(1), 51. Https://Doi.Org/10.24832/Jpnk.V4i1.1157

Purwoko, R. Y., Nugraheni, P., \& Nadhilah, S. (2020). Analisis Kebutuhan Pengembangan E -Modul Berbasis Etnomatematika Produk Budaya Jawa Tengah. Jurnal Penelitian Matematika Dan Pendidikan Matematika, 5(1), 1-8.

Rahmiyati, \& Darmaji. (2014). Pengembangan Modul Elektronik Dengan Pendekatan Saintifik Pokok Bahasa Hukum Termodinamika Untuk Sma/Ma Kelas Xi. 154, 1-13.

Riyanti, Y. (2021). Edukatif: Jurnal Ilmu Pendidikan Pengaruh Kemandirian Belajar Terhadap Hasil Belajar Matematika Siswa Sekolah Dasar. 3(4), 1309-1317.

S.Sirate, S. F., \& Ramadhana, R. (2017). Pengembangan Modul Pembelajaran Berbasis Keterampilan Literasi. Inspiratif Pendidikan, 6(2), 316-335. Https://Doi.Org/10.24252/Ip.V6i2.5763

Suarsana, I. M., \& Mahayukti, G. A. (2013). Pengembangan E-Modul Berorientasi Pemecahan Masalah Untuk Meningkatkan Keterampilan Berpikir Kritis Mahasiswa. Jurnal Nasional Pendidikan Teknik Informatika (Janapati), 2(3), 193. Https://Doi.Org/10.23887/Janapati.V2i3.9800

Sugiyarti, L., Arif, A., \& Mursalin. (2018). Pembelajaran Abad 21 Di Sd. Prosiding Seminar Dan Diskusi Nasional Pendidikan Dasar, 439-444.

Sugiyono. (2019). Metode Penelitian Kuantitatif Kualitatid Dan R\&D. Penerbit Alfabeta Bandung.

Sulistyani, N., \& Deviana, T. (2019). Analisis Bahan Ajar Matematika Kelas V Sd Di Kota Malang. Jurnal Pemikiran Dan Pengembangan Sekolah Dasar (Jp2sd), 7(2), 133-141.

Suwartaya, Anggraeni, E., Rujiyati, Saputra, S., \& Setyaningsih, D. A. (2020). Panduan Pengembangan Bahan Ajar Pembelajaran Jarak Jauh (Ba-Pjj) Sekolah Dasar.

Vitrianingsih, D., Aulianingsih, I., \& Yuliani, H. (2021). Analisis Kebutuhan Pengembangan Modul Elektronik (E-Module) Ipa Terintegrasi Islam. Jurnal Ilmiah Pendidikan Fisika, 5(1), 27. Https://Doi.Org/10.20527/Jipf.V5i1.2525

Wiryanto. (2020). Proses Pembelajaran Matematika Di Sekolah Dasar Di Tengah Pandemi Covid-19. Jurnal Review Pendidikan Dasar: Jurnal Kajian Pendidikan Dan Hasil Penelitian, 6(2), 125-132.

Yasin, S., \& Enver, T. (2007). Students' Difficulties With Application Of Definite Integration. Educaţia Matematică, $3(1)$,

$15-27$ Https://Www.Researchgate.Net/Profile/Enver_Tatar/Publication/242685561_Studentsdifficulties_With_ Application_Of_Definite_Integration_1/Links/54ed455f0cf2465f5330ec6d.Pdf 